\title{
Gender perspectives on agroforestry practices in Mt. Merapi hazards and risks prone area of Indonesia
}

\author{
ZUHUD ROZAKI ${ }^{1, \vartheta}$, NUR RAHMAWATI ${ }^{1}$, OKI WIJAYA ${ }^{1}$, FADHILAH SAFITRI ${ }^{1}$, MASATERU SENGE ${ }^{2}$, \\ MOHD FAUZI KAMARUDIN ${ }^{3}$ \\ ${ }^{1}$ Department of Agribusiness, Faculty of Agriculture, Universitas Muhammadiyah Yogyakarta. Jl. Brawijaya, Kasihan, Bantul 55183, Yogyakarta, \\ Indonesia. Tel./fax.: +62-274-387656, `email: zaki@umy.ac.id \\ ${ }^{2}$ Union Ltd. Gifu, 5010106, Japan \\ ${ }^{3}$ Universiti Teknikal Malaysia Melaka. Jl. Hang Tuah Jaya, 76100 Durian Tunggal, Melaka, Malaysia
}

Manuscript received: 7 June 2021. Revision accepted: 27 June 2021.

\begin{abstract}
Rozaki Z, Rahmawati N, Wijaya O, Safitri F, Senge M, Kamarudin MF. 2021. Gender perspectives on agroforestry practices in Mt. Merapi hazards and risks-prone area of Indonesia. Biodiversitas 22: 2980-2987. Despite the risk and hazards of the Mt. Merapi prone area, people continue to stay in the area as Agroforestry Adopters. This study aims to analyze the gender perspectives on agroforestry (AF) practices in the Mt. Merapi prone area. 128 men and 86 women were randomly selected from four different areas. Descriptive analysis, independent t-test, and logistic multinomial regression were used to analyze the data. Gender issue in AF practices is found in some parts of the practices. For example, women are more predominant in marketing the products rather than men, whilst the men are predominant in activities that need more strength such as planting. An external factor that is significant is the different impacts of farmers support groups on men and women. Meanwhile, factors such as capital access and AF easiness do not show significant differences between men and women. In other words, these two variables are felt the same among men and women when practicing AF. As for the contribution of $\mathrm{AF}$, social aspect is found to show significant differences, whilst economic and ecology do not show significant differences to both the men and women. Additionally, factors that affect the perspectives on AF contribution vary among the respondents across both groups of men and women. This study suggests that the different perspectives and factors that are affecting AF farmers can be used to develop future AF promotion programs.
\end{abstract}

Keywords: Agroforestry, gender perspectives, hazards and risks, Indonesia, Mt. Merapi

\section{INTRODUCTION}

Bachri et al. (2015) in their research stated that the reason people choose to stay and live in the Mt. Merapi, Indonesia prone area is a complex interaction between human and volcano environment. In his study on Mt. Bromo, Indonesia, it is shown that people won't move to other safer places because despite exposure to negative consequences, the people also enjoy benefits and opportunities, spiritually and socio-culturally. Additionally, they felt connected with their ancestors. These findings are supported by Napsiah et al. (2017), who showed that people who live in Mt. Merapi enjoy the economic blessings of the area, such as fertile land and tourist visits. Mt. Merapi is an active volcano which mountain covers Central Java (i.e. Boyolali District, Klaten District, and Magelang District) and Yogyakarta (i.e. Sleman District). In 2006 and 2010, Mt. Merapi had erupted, which greatly impacted the surrounding and its people (Ratdomopurbo et al. 2013; Maharani et al. 2016).

Some people who were much impacted by the 2006 or 2010 eruptions continue to move back to their houses in the volcano-prone area because of economic motivation and assets preservation (Nofrita and Krol 2014). In Mt. Merapi, people livelihood is dominated by farmers and sand miners, respectively (Bachri et al. 2015). Rozaki et al. (2021) showed that AF has been practiced by many people in Mt.
Merapi's surrounding areas due to the benefits of this agricultural system such as water conservation. Nephawe et al. (2021) explained that water conservation is important in the agriculture sector. A farmer livelihood relies on vegetables or other crops and other livestock that is suitable in mountainous areas. These people are known as agroforestry (AF) adopters and they cultivate agricultural land or forest activities that combine crops and trees. Besides that, some are sand miners, a livelihood that became popular because the income is stable (Rahman et al. 2016). People who live in volcano-prone areas have different strategies for coping with hazards from volcano activities. In the Mt. Merapi prone area, many people practice AF. Bachri et al. (2015) stated that in mountainous area, people commonly rely on natural resources. Utami et al. (2018) explained that AF practices are common to be practiced as a coping mechanism for disasters such as eruptions.

In adjacent, gender study on agriculture and environment is important due to many aspects and has recently become a pertinent current issue (Thompson-Hall 2016). Men and women have participated in agriculture activities all around the world. However, which gender dominates these activities varies from one another. For example, in Thailand and Philippines, women are active in agricultural activities, unlike in Indonesia and Myanmar, where men are more active (Akter et al. 2017; Rietveld et al. 2020). This happened because gender disaggregation is happening in 
all sectors. In agriculture, study on gender perspective has found that female laborers show positive employment effects, despite belonging to the most vulnerable groups (Rao and Qaim 2013). Previous studies also found that gender norms, such as women cannot work outside, can discourage women from being active in agricultural activities (Khandekar et al. 2019; Rietveld et al. 2020). In another study, Carter and Allendorf (2016) stated that gender study is important because men and women usually have different perceptions of certain issues such as adaptation regarding disasters. Gender gaps in agriculture are caused by disparities in input use (labor) and asset ownership. Despite this, female laborers are more participative in agriculture activities because of male laborers shortage.

One benefit of AF is it reduces poverty and land degradation, as well as improves food security. This is because AF practice can be used for food diversification especially for fruit trees (Ahmad et al. 2017). Suryanto (2011) also showed that AF contributes to biodiversity conservation. Therefore, many people are practicing this system including in Mt. Merapi. Additionally, gender risk and hazard perception are critical in understanding disaster risks. This knowledge is used to determine the appropriate community measures during disasters (Bee 2016; Khan et al. 2020). Beliefs, rather than socio-economic, experience, or risk, underlie the different attitudes or perceptions (Carter and Allendorf 2016). Moment in disaster management has second role and commonly don't get proper recognition (Rakib et al. 2017). In terms of disaster adaptation, men and women are found to have no differences. According to Adzawla et al. (2019), the difference lies in the level of the adaptation, not the types of adaptations. This is because both genders receive the same impact from the disaster (Adzawla et al. 2019).

Catacutan and Naz (2015) stated that women have higher constraints in adopting AF compared to men. This is caused by their low education level and poor access to extension of assistance. Nevertheless, women are more likely to adopt the AF system since men prefer monoculture (Blare and Useche 2015). Studies on gender in the AF practice cannot ignore other variables such as age, marital status, life-cycle stage, labor availability, and access to market that impact the AF practices (Gelinas et al. 2015). According to Dey et al. (2014), AF is being practiced by men and women since it contributes to environmental sustainability.

At the Mt. Merapi hazards and risks-prone area, women and men are the main actors in the AF practices. This is because, women lead some families due to problems relating to the husbands such as old age, illness or handicapped. One other reason is due to divorce. In this aspect, studies have shown that gender impacts agriculture and its environment. Therefore, it is important to understand the whole context especially relating to how each gender approaches different issues relating to the main activity, in this case, AF (Thompson-Hall 2016). Carter and Allendorf (2016) added that gender study is important because men and women generally have different perceptions. This study aims to analyze gender perspectives of AF practices in Mt. Merapi prone area.

\section{MATERIALS AND METHODS}

\section{Study area}

Agroforestry practices are conducted by both genders: men and women. As such they do have different perspectives in many aspects including AF practices. Four different areas surrounding Mt. Merapi were chosen to represent the gender perspectives which are: Jemowo Village (Tamansari Sub-district, Boyolali District) in East part, Telogolele Village (Selo Sub-District, Boyolali District) in North part, Krinjing Village (Dukun Subdistrict, Magelang District) in West part, and Glagaharjo Village (Cangkringan Sub-district, Sleman District) in South part. These areas represent the surrounding areas of Mt. Merapi because they are located on different sides of the mountain (as seen in Figure 1). Additionally, the risk and hazard of this area differ based on the degree of lava flow to the impacted areas. In recent incidents, the lava tends to flow to the Cangkringan Sub-district area.

\section{Sampling procedure and data collection}

This study involves randomly 214 AF adopters as respondents, they consist of 128 men, and 86 women randomly selected from four different areas: Jemowo Village (East), Tlogolele Village (North), Krinjing Village (West) and Glagaharjo Village (South). These four areas were believed to represent all of the Mt. Merapi-prone areas. There are three variables in this study; demographic of respondents, external factors and AF contributions in the Mt. Merapi prone area. Likert scale, interval, and descriptive statistics were used to measure variables (Tables 1-3). The questionnaire was constructed from observation and some literature regarding the AF practices, especially in terms of gender issues. Some questions regarding AF practices were retrieved and modified from Rural Household Multi-Indicator Survey or RHoMIS (https://www.rhomis.org/). The research instruments then were analyzed using the validity and reliability tests using Cronbach's alpha test. All questions on the variables are valid and reliable to be used for collecting data. Subsequently, observation and in-depth interviews with key informants were done to support the findings.

In-depth interviews with participants were carried out during the eruption in January 2021, where the climax activity was on 27 January 2021 (Mustaqim 2021). This interview was done to understand the real-time condition of farmers during the Mt. Merapi eruption. External factors consist of three variables, they are farmers' group support, capital access and AF easiness. These variables were chosen because the observation that has been done shows that these variables are predominant variables regarding the external factor that effect the farmers' thoughts. Meanwhile, the AF contribution variables are including economic, ecology, and social. These variables are common for any farming system practice, including AF. In addition, gender work on AF also has been included in the questionnaire with open question "What women and men do in AF practice?" "Who is dominant?", and was analyzed descriptively due to open question. 

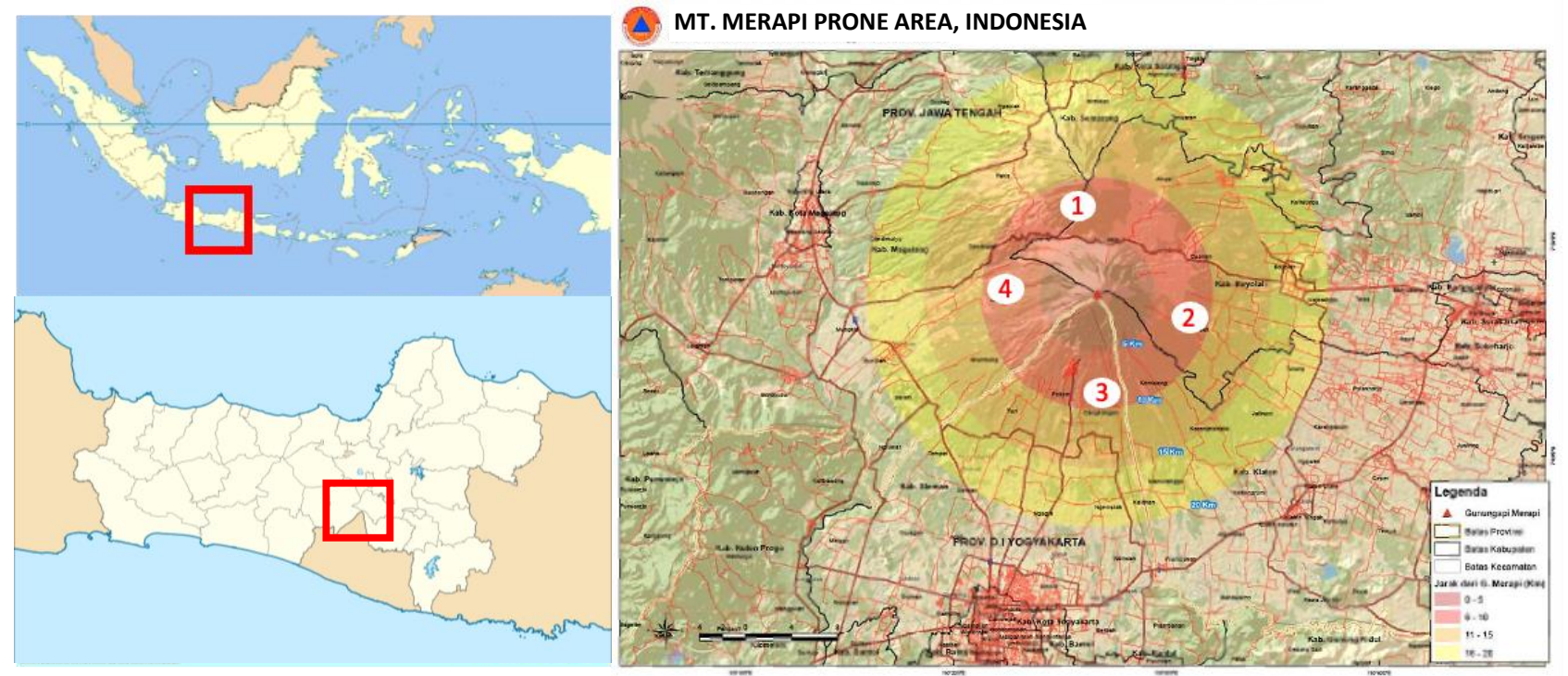

Figure 1. Research site at four different areas surrounding Mt. Merapi, Central Java and Yogyakarta provinces, Indonesia, i.e.: 1. Telogolele Village (Selo Sub-District, Boyolali District) in North part, 2. Jemowo Village (Tamansari Sub-district, Boyolali District) in East part, 3. Glagaharjo Village (Cangkringan Sub-district, Sleman District) in South part, 4. Krinjing Village (Dukun Sub-district, Magelang District) in West part

Table 1. Demographic variable

\begin{tabular}{ll}
\hline Variable/indicator & Measurement \\
\hline Gender & Male or Female \\
Age & Interval (5 scales) \\
Education & None to Diploma or University \\
& (5 scales) \\
Farming experience & Interval (5 scales) \\
\hline
\end{tabular}

Table 2. External factor variables

\begin{tabular}{ll}
\hline Variable & Indicator \\
\hline $\begin{array}{l}\text { Farmers' group } \\
\text { support }\end{array}$ & Farmers' group support the AF practices \\
Capital access & Financial support such as credit access is easy \\
AF easiness & AF is easy to be practiced \\
\hline Note: Measurement: 1 (strongly disagree) - 5 (strongly agree)
\end{tabular}

Table 3. Agroforestry contribution variable

\begin{tabular}{ll}
\hline Variable & Indicator \\
\hline Economic & 1. AF support food availability \\
& 2. AF contribute to family income \\
& 3. AF become good livelihood \\
Ecology & $\begin{array}{l}\text { 1. AF can repair and conserve the land } \\
\text { 2. AF protect the land and crops from Mt Mt. } \\
\text { Merapi eruption }\end{array}$ \\
& $\begin{array}{l}\text { 3. AF can protect the water conservation } \\
\text { Social }\end{array}$ \\
& $\begin{array}{l}\text { 1. AF can increase the social activities } \\
\text { 2. AF social activities can support the Mt. Merapi } \\
\text { mitigation efforts }\end{array}$ \\
& 3. AF networks provide mitigation education \\
\hline
\end{tabular}

Note: Measurement: 1 (strongly disagree) - 5 (strongly agree)

\section{Analytical technique}

Descriptive method is used to describe and present the findings. Usage of mean, frequency, percentage, and standard deviation is used to present the variables and show the differences and similarities of gender perspectives. Independent t-test is used to understand the significant differences between men and women perceptions. Additionally, logistic multinomial regression is used to show the factors affecting the perceptions, with demographic of respondents and external factor as independent variables, and AF contribution as the dependent variable. SPSS 26 was used to analyze the data.

\section{RESULTS AND DISCUSSION}

\section{Demographic of respondents}

Age generally affects the perspective of the respondents. In this study, both men and women age is dominated by 28 to 40 years old, with men at $28.13 \%$ and women at $33.72 \%$ respectively. Both genders have participants at the age of more than 64 years old, with men at $17.97 \%$ and women at $8.14 \%$. Aging problems occur not only for men, but also for women. The mean of age for men is 49.23 years old, and for women is 43.64 years old (Table 4). This age is quite old for physical works such as agriculture (Adzawla et al. 2019).

In terms of the education of the respondents, the finding shows that majority of respondents only reach up elementary school, with men at 50\% and women at $59.30 \%$ respectively. Only a few participants reached tertiary education, with men at $3.91 \%$ and women at $2.32 \%$. Majority of the participants are farmers and are they are located in rural mountainous areas. Hence, many respondents did not care too much about education. 
However, today's generation is different. Many of the respondents' children have good education, with the minimum reaching high school. This awareness grew because the educational facilities have developed and the government program for free education is tertiary. Additionally, this study found that both men and women have many years of experience in farming, with a mean of 28.86 years and 23.37 years respectively. This is because many respondents started working in agriculture in their early 20s. This gives them good experience in practicing AF.

\section{Gender perspectives}

\section{External factors}

The farmers' group in Indonesia is operating quite well in many areas due to continuous support from the governments through various agriculture programs that are delivered to the farmers through the farmers' group. Furthermore, education about recent technologies, or other issues are brought to the farmers through farmers' groups. The gender perspectives regarding farmers' group support on AF show that men have higher mean. This is because men are more engaged with farmers' groups as compared to women (Figure 2). Despite this, both men and women stated that support from the farmers' group support is not big enough as shown with a mean of less than 3 . However, in Tlogolele, the farmers' group "Kepengen Maju" is intensely promoting $\mathrm{AF}$ for land restoration and conservation. Through education board, or posters that explain the benefits of AF (Figure 3), knowledge is disseminated. For example, this board explains that AF can protect the biodiversity of plants, prevent erosion and landslide, and conserve water and land.

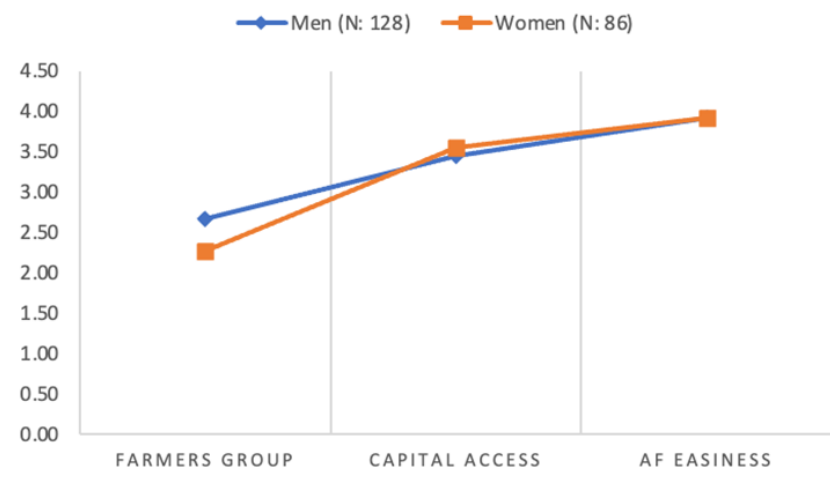

Figure 2. External factors (mean)

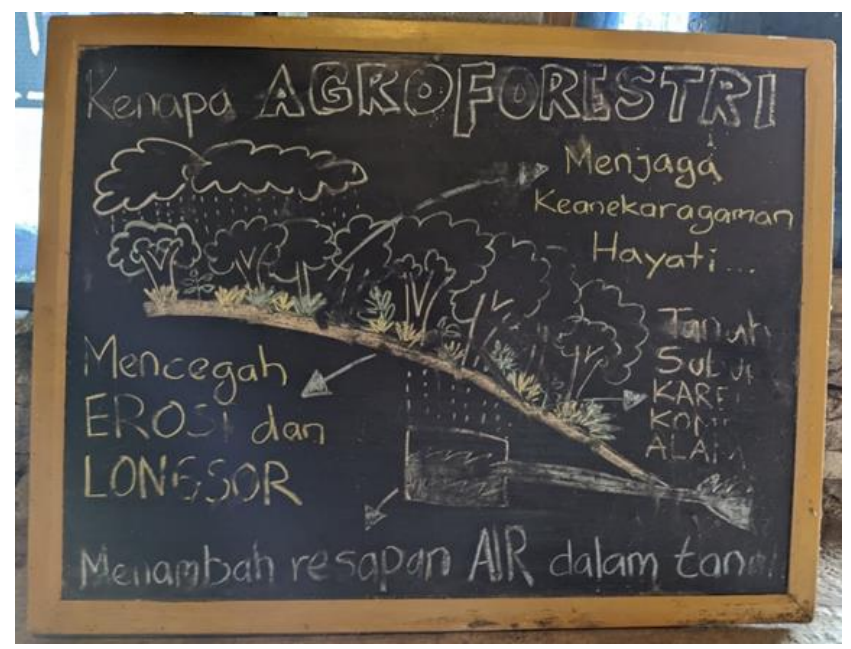

Figure 3. AF education board in farmers' group "Kepengen Maju"

Table 4. Demographic of respondents

\begin{tabular}{|c|c|c|c|c|c|c|c|c|}
\hline & \multicolumn{4}{|c|}{ Men (N: 128) } & \multicolumn{4}{|c|}{ Women (N: 86) } \\
\hline & Freq. & Percent & Mean & Sd. & Freq. & Percent & Mean & Sd. \\
\hline Age & & & 49.23 & 15.54 & & & 43.64 & 12.58 \\
\hline $15-27$ & 9 & 7.03 & & & 12 & 13.95 & & \\
\hline $28-40$ & 36 & 28.13 & & & 29 & 33.72 & & \\
\hline $41-53$ & 27 & 21.09 & & & 24 & 27.91 & & \\
\hline $54-64$ & 33 & 25.78 & & & 14 & 16.28 & & \\
\hline More than 64 & 23 & 17.97 & & & 7 & 8.14 & & \\
\hline Education & & & 2.37 & 0.99 & & & 2.29 & 0.85 \\
\hline None & 20 & 15.63 & & & 10 & 11.63 & & \\
\hline Elementary & 64 & 50.00 & & & 51 & 59.30 & & \\
\hline Junior & 26 & 20.31 & & & 17 & 19.77 & & \\
\hline High & 13 & 10.15 & & & 6 & 6.98 & & \\
\hline Diploma/Univ. & 5 & 3.91 & & & 2 & 2.32 & & \\
\hline Farming experience & & & 28.86 & 16.73 & & & 23.37 & 13.97 \\
\hline $0-10$ & 22 & 17.19 & & & 19 & 22.09 & & \\
\hline $11-20$ & 26 & 20.31 & & & 19 & 22.09 & & \\
\hline $21-30$ & 27 & 21.09 & & & 24 & 27.91 & & \\
\hline $31-40$ & 23 & 17.97 & & & 11 & 12.79 & & \\
\hline 41 and more & 30 & 23.44 & & & 13 & 15.12 & & \\
\hline
\end{tabular}


In order to practice AF or agriculture, farmers need capital. Generally, farmers in rural areas come up with their own capital. Despite Indonesia loan institutions growing fast, the high interest rate is a hurdle for the AF formers to take loan. In this study, with regards to capital access, women are found to have higher perception mean. In rural areas, women are commonly known to have knowledge on how and where to take loans due to their daily activities. The study found that women used to loan money in order to achieve daily necessities. In adjacent, this study shows the different perceptions between men and women regarding the difficulty of practicing AF with both genders showing similar mean. The reason to this is because AF in Mt. Merapi prone area has started a long time ago. Therefore, current generation felt that AF is not difficult.

Levene's test score above shows that only farmers' group shows significant difference between men and women (Table 5), at 0.079. This means that the data variance between men and women is heterogeneous. The ttest shows a significant score of 0.031 . This depicts that the perspective on farmers' groups between men and women is significantly different. This study found that other factors are not significant such as capital access and AF easiness.

\section{AF contributions}

Perception of AF contribution is divided into three: economic, ecology, and social. Economic refers to how AF can provide food, generate income, and good livelihood. The mean score of economic contribution from AF shows that women have higher mean than men (Figure 4). Perhaps because women usually manage the family's economy, women may have more understanding of the AF contribution to their family economy. Amare et al. (2018) showed that AF contributes to household economy through the AF products' selling.

Ecology relates to the contribution of AF on land conservation, water conservation, and preventing erosion and landslide. For total average, men and women show similar mean. This may be because men and women felt the same about the damage from Mt. Merapi which impacted their lives. This is most especially in the most severe damage area from Mt. Merapi eruption which is Glagaharjo. In this area, efforts to restore the land such as using AF system are more needed with the practicing of AF.

Table 5. Independent t-test results for external factors

\begin{tabular}{lccccc}
\hline \multirow{2}{*}{ Variables } & \multicolumn{2}{c}{ Levene's Test } & \multicolumn{2}{c}{ t-test } \\
\cline { 2 - 6 } & F & Sig. & t & df & Sig. (2-tailed) \\
\hline Farmers Group & 3.101 & 0.079 & 2.167 & 212 & 0.031 \\
Capital Access & 0.456 & 0.500 & -0.923 & 212 & 0.357 \\
AF Easiness & 0.263 & 0.608 & 0.047 & 212 & 0.962 \\
\hline
\end{tabular}

Table 6. Independent t-test result for AF contribution

\begin{tabular}{lccccc}
\hline \multirow{2}{*}{ Variables } & \multicolumn{2}{c}{ Levene's Test } & \multicolumn{3}{c}{ t-test } \\
\cline { 2 - 6 } & F & Sig. & t & df & Sig. (2-tailed) \\
\hline Economic & 0.005 & 0.943 & -1.071 & 212 & 0.285 \\
Ecology & 0.047 & 0.829 & -0.021 & 212 & 0.983 \\
Social & 0.109 & 0.740 & 2.609 & 212 & 0.009 \\
\hline
\end{tabular}

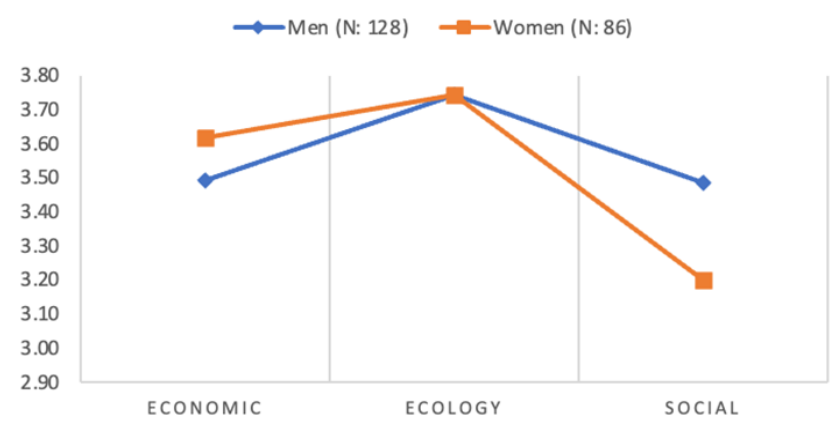

Figure 4. Agroforestry contribution (mean)

From the independent t-test result, only social variable shows significant 0.009 value (Table 6). This depicts that the perspectives of men and women on social variables are significantly different. Through AF practices, the social interaction or engagement is more intense especially to increase the AF practices as one of method of Mt. Merapi disaster mitigation.

\section{Gender work on AF}

In practicing $\mathrm{AF}$, both men and women contribute to maintaining AF. In the Mt. Merapi prone area, AF and agriculture practices involve women significantly. This study shows some AF activities that women do. Nevertheless, this varies in each family. Common AF activities that women do are planting, fertilizing, harvesting (crop, fruit, or milk), taking care of cattle, and selling products. Additionally, some respondents said that women do what men do in $\mathrm{AF}$ and agriculture. The difference however lies in the period of time spent to perform these activities.

\section{Gender response and actions toward Mt. Merapi hazards}

Both men and women are equally faced with the hazards from Mt. Merapi. The latest eruption in January 2021 did not cause major damage. However, through indepth interviews, the gender perspective in responding to the hazards is revealed. Some people who live within $5 \mathrm{~km}$ from the top of Mt. Merapi have fled (Wikanto 2021). People who fled were generally the vulnerable group such as the elderly, women, and children. For the men, although they fled, they only stay in nearby shelters at night, and during the daylight, they will come back to their homes to take care of the livestock, agriculture, as well as protect their properties. These conditions are similar during the big eruption of 2010. Despite the hazards, residents still came back to their homes during the daylight. For those who did not flee, they continue to do the daily activities while paying attention to the latest news or instructions by the government relating to the Mt. Mt. Merapi activities.

\section{Factors affecting gender perspectives}

Through Multinomial Logistic Regression, the factors that have effect on gender perspective have been analyzed. For both men and women, the model is fit with Pearson with more than 0.05 (as seen in Tables 7 and 8). The data 
variance can be seen from R2, with men scoring at $67 \%$ to $74 \%$, and women at $52 \%$ to $78 \%$. AF's perception of ecology shows that men are affected by age, family number, farming experience, and AF easiness. Meanwhile, for the women, the result shows that they are only affected by farming experience.

As for the AF contribution to economic such as family income and good livelihood, men are affected by education, family number, farming experience, farmers' group support, and capital access. These independent variables commonly affect the economics of the farmers life, especially when men are the head of the household. Meanwhile, women are only affected by capital access. This may be because women are commonly found to manage the family finance in rural inhabitants. If they are short of cash, they would usually lend from neighbors or small daily necessities shops. These habits seem to contribute to the perception of AF contribution to economic is affected by capital access.

AF contribution to social aspects such as increasing the social engagement due to AF practice shows significant differences between the two gender with the men impacted by education, family number, farming experience, and capital access. Meanwhile, for the women, they are impacted by all independent variables except farming experience. In this aspect, Khandekar et al. (2019) explained that socio-cultural norms impacted women by limiting their access to decision-making and adaptive capacity.

\section{Discussion}

Both men and women well practice AF in Mt. Merapi prone area. The practice of this system is part of the household efforts to make better living from the agriculture sector. Additionally, that the majority of the farmers in Mt. Merapi prone area are practicing AF since their ancestors because this system benefits them. Blare and Useche (2015) stated that AF practices benefit the farmers such as having trees and crop products. Kiptot (2015) added that AF has huge potential for improving rural household life because AF is low-cost and provides diverse products that can support households.

This study has revealed that gender issue is happening in all sectors, including agriculture. Glemarec (2017) stated that gender issue in agriculture is closely related to production. In Indonesia itself, agriculture system that men dominate is becoming a culture in Indonesia. On the other hand, women dominate the selling of products, both from crops or trees (Villamor et al. 2015). In AF practices, gender issue is also considered as an important aspect that should not be neglected. Catacutan and Naz (2015) stated that globally, women have significant role in AF practice, especially in the establishment and maintenance.

This study shows that gender perception on the farmers group variable has significant differences. In Indonesia, common farmers groups are dominated by men. Therefore, the different perspective on the farmers group benefit for AF practice has been revealed. Kiptot (2015) stated that women need to be given more space by the authorities to manage $\mathrm{AF}$ in order to increase women participation in $\mathrm{AF}$ practices.

Table 7. Factors affecting men perspective

\begin{tabular}{lllllll}
\hline \multirow{2}{*}{ Variables } & Economic & \multicolumn{3}{c}{ Ecology } & & Social \\
\cline { 2 - 7 } & Chi-Square & Sig. & Chi-Square & Sig. & Chi-Square & Sig. \\
\hline Age & 9.759 & 0.879 & 27.401 & $0.007 * *$ & 17.787 & 0.122 \\
Education & 41.025 & $0.001^{* *}$ & 14.485 & 0.271 & 27.228 & $0.007 * *$ \\
Family Number & 28.981 & $0.024^{*}$ & 21.079 & 0.049 & 41.452 & $0.000^{* *}$ \\
Farming Experience & 42.673 & $0.000^{* *}$ & 34.799 & $0.001^{* *}$ & 24.418 & 0.018 \\
Farmers Group Support & 33.262 & $0.007^{* *}$ & 15.987 & 0.192 & 12.855 & 0.380 \\
Capital Access & 34.157 & $0.001^{* *}$ & 11.887 & 0.220 & 22.411 & $0.008^{* *}$ \\
AF Easiness & 9.759 & 0.879 & 27.401 & 0.007 & 17.787 & 0.122 \\
Pearson (Goodness of fit) & \multicolumn{2}{c}{1.000} & & 1.000 & 0.736 & 0.000 \\
$\mathrm{R}^{2}$ (Nagelkerke) & \multicolumn{2}{c}{0.676} & & & & 0.672 \\
\hline
\end{tabular}

Note: *Significant at 0.05 level, $* *$ Significant at 0.01 level

Table 8. Factors affecting women perspective

\begin{tabular}{lllllll}
\hline & Economic & & Ecology & \multicolumn{3}{l}{ Social } \\
\cline { 2 - 7 } & Chi-Square & Sig. & Chi-Square & Sig. & Chi-Square & Sig. \\
\hline Age & 8.804 & 0.720 & 7.337 & 0.835 & 38.421 & $0.000^{* *}$ \\
Education & 12.696 & 0.392 & 12.564 & 0.401 & 1523.673 & $0.000^{* *}$ \\
Family Number & 10.923 & 0.536 & 16.393 & 0.174 & 1282.097 & $0.000^{* *}$ \\
Farming Experience & 13.494 & 0.334 & 23.948 & $0.021^{*}$ & 7.314 & 0.836 \\
Farmers Group Support & 18.255 & 0.108 & 7.844 & 0.797 & 216.860 & $0.000^{* *}$ \\
Capital Access & 29.785 & $0.000^{* *}$ & 14.344 & 0.111 & 68.621 & $0.000^{* *}$ \\
AF Easiness & 8.804 & 0.720 & 7.337 & 0.835 & 38.421 & $0.000^{* *}$ \\
Pearson (Goodness of fit) & \multicolumn{2}{c}{0.977} & & 1.000 & 0.757 & \\
$\mathrm{R}^{2}$ (Nagelkerke) & \multicolumn{2}{c}{0.777} & & & & 0.522 \\
\hline
\end{tabular}

Note: *Significant at 0.05 level, $* *$ Significant at 0.01 level 
Meanwhile, for credit access and AF easiness, the finding shows the same. Credit access for farmers comes from banks or other local financial institutions. This access is the same among agricultural systems, not limited to the AF practices only. This study also revealed the economic and ecological aspects in terms of AF contribution. This shows that findings from other studies that AF contributes to the economy (Desmiwati et al. 2021) and conservation (Budianto 2021) of the environment are proven.

In terms of the gender issue, previous studies have found that men dominate in almost all AF practice activities, while women dominate in maintenance and marketing (Bourne et al. 2015; Mulyoutami et al. 2015). This study shows a similar result where the majority of respondents stated that men are dominating in almost all factors. However, some respondents stated that men and women are equal in managing their AF. In another study, Bergman Lodin et al. (2019) showed that women are less mobile in agriculture due to social norms. In this study, the finding shows that in the current generation, farmers are more focused on earning money as compared to preserving norms.

The study also revealed that factors that affect the men and women perspectives on AF practices vary. These findings were supported by Bose (2015); Bourne et al. (2015); Gelinas et al. (2015). Their studies stated that gender perspective is affected by education, age, access to market, and economy. Regarding the AF adoption rate, women have more constraints on adopting AF as compared to men. In a study by Fajarwati (2015), women are found to be more sociable. Similarly, this study shows that women are more engaged in social activities as compared to men due to having more at home and in communities.

Through the results of this study, gender issue in AF practices is found to exist and this issue needs to be considered in the AF future promotion efforts. As Kiptot and Franzel (2011) stated, understanding the women roles in AF management can bring more benefits both for men and women. Despite the various findings regarding $\mathrm{AF}$ practices, including gender issues, many researchers are interested to study AF due to its benefit to reduce poverty and land degradation (Ahmad et al. 2017). Moreover, in terms of Mt. Merapi risk and hazards, the AF practices contribute to mitigation strategies (Rampengan 2015).

In conclusion, AF practices in Mt. Merapi prone area involve both men and women in any type of work. Men are more involved in physical activities, and women are more involved in maintenance. Additionally, women are found predominant in AF products' selling. The perception of men and women on AF practices in specific variable, shows significant differences. Meanwhile, for the AF contribution, only social variable shows significant difference. Statistically, both men and women have the same perception of AF contributions in terms of economics and ecology. Beyond the economic benefits, AF practices in Mt. Merapi prone area contribute for conserving land and protection from erosion. Moreover, when eruption happens, it contributes towards the protection of assets. These findings can strengthen the AF expansion program for both human and environmental benefits. Gender perception on AF contribution on economic, ecology, and social will affect their actions toward AF practices. Thus, education regarding the benefits of AF practices needs to be increased because this practice has good benefit in facing the Mt. Merapi disaster, also contributing to boosting the economy and conservation of the land. Subsequently, social engagements need to be supported and increased because these can promote AF practices and be the source of various important information. Even though social norm is not a challenge, this issue needs to be addressed to motivate and increase women participation in $\mathrm{AF}$.

\section{ACKNOWLEDGEMENTS}

The authors would like to express huge gratitude to Universitas Muhammadiyah Yogyakarta, Indonesia for the funding and support to this research through an internal research grant. The authors also would like to convey gratitude to Universiti Teknikal Malaysia Melaka, Malaysia for the collaboration and support.

\section{REFERENCES}

Adzawla W, Azumah SB, Anani PY, Donkoh SA. 2019. Gender perspectives of climate change adaptation in two selected districts of Ghana. Heliyon 5 (11): e02854. DOI: 10.1016/j.heliyon.2019.e02854.

Ahmad F, Goparaju L, Qayum A. 2017. Agroforestry suitability analysis based upon nutrient availability mapping: A GIS-based suitability mapping. AIMS Agric Food 2 (2): 201-220. DOI: 10.3934/agrfood.2017.2.201.

Akter S, Rutsaert P, Luis J, Htwe NM, San SS, Raharjo B Pustika A. 2017. Women's empowerment and gender equity in agriculture: A different perspective from Southeast Asia. Food Pol 69: 270-279. DOI: 10.1016/j.foodpol.2017.05.003.

Bachri S, Stötter J, Monreal M, Sartohadi J. 2015. The calamity of eruptions, or an eruption of benefits? Mt. Bromo human-volcano system a case study of an open-risk perception. Nat Hazards Earth Syst Sci 15 (2): 277-290. DOI: 10.5194/nhess-15-277-2015.

Bee BA. 2016. Power, perception, and adaptation: Exploring gender and social-environmental risk perception in northern Guanajuato, Mexico. Geoforum 69, 71-80. DOI: 10.1016/j.geoforum.2015.12.006

Bergman Lodin J, Tegbaru A, Bullock R, Degrande A, Nkengla LW, Gaya HI. 2019. Gendered mobilities and immobilities: Women's and men's capacities for agricultural innovation in Kenya and Nigeria. Gender Place Cult 26 (12): 1759-1783. DOI: 10.1080/0966369X.2019.1618794.

Blare T, Useche P. 2015. Is there a choice? Choice experiment to determine the value men and women place on cacao agroforests in coastal Ecuador. Intl For Rev 17 (4): 46-60. DOI: $10.1505 / 146554815816086390$.

Bose P. 2015. India's drylands agroforestry: a ten-year analysis of gender and social diversity, tenure and climate variability. Intl For Rev 17 (4): 85-98. DOI: 10.1505/146554815816086435

Bourne M, Kimaiyo J, Tanui J, Catacutan D, Otiende V. 2015. Can gender appreciation of trees enhance landscape multifunctionality? A case of smallholder farming systems on Mount Elgon. Intl For Rev 17 (4): 33-45. DOI: $10.1505 / 146554815816086480$.

Budianto G. 2021. Land use planning for disaster-prone areas in southern region of mount Mt. Merapi. Agrivita 43 (1): 1-12. DOI: 10.17503/agrivita.v1i1.2774.

Carter NH, Allendorf TD. 2016. Gendered perceptions of tigers in Chitwan National Park, Nepal. Biol Conserv 202: 69-77. DOI: 10.1016/j.biocon.2016.08.002.

Catacutan D, Naz F. 2015. Gender roles, decision-making and challenges to agroforestry adoption in Northwest Vietnam. Intl For Rev 17 (4): 22-32. DOI: $10.1505 / 146554815816086381$. 
Amare D, Wondie M, Mekuria W, Darr D. 2018. Agroforestry of smallholder farmers in Ethiopia: practices and benefits. Small-scale For 18 (1): 39-56. DOI: 10.1007/s11842-018-9405-6.

Desmiwati D, Verisa TO, Aminah A, Safiti AD, Hendarto KD, Wisudayati TA, Royani H, Dewi KH, Raharjo SHI, Sari DR. 2021. Contribution of agroforestry systems to farmer income in state forest areas: A case study of Parungpanjang, Indonesia. Forest Soc 5 (1) 109-119. DOI: $10.24259 /$ fs.v5i1.11223.

Dey S, Resurreccion BP, Doneys P. 2014. Gender and environmental struggles: voices from Adivasi Garo community in Bangladesh. Gender Place Culture 21 (8): 945-962. DOI 10.1080/0966369X.2013.832662.

Fajarwati A, Mei ETW, Hasanati S, Sari IM. 2016. The productive an reproductive activities of women as form of adaptation and postdisaster livelihood strategies in Huntap Kuwang and Huntap Plosokerep. Procedia Soc Behav Sci 227: 370-377. DOI: 10.1016/j.sbspro.2016.06.084.

Gelinas N, Lavoie A, Labrecque MF, Olivier A. 2015. Linking women, trees and sheep in Mali. Intl For Rev 17 (4): 76-84. DOI: $10.1505 / 146554815816086462$

Glemarec Y. 2017. Addressing the gender-differentiated investment risks to climate-smart agriculture. AIMS Agric Food 2 (1): 56-74. DOI: 10.3934/agrfood.2017.1.56

Khan AA, Rana I, Nawaz A. 2020. Gender-based approach for assessing risk perception in a multi-hazard environment: A study of high schools of Gilgit, Pakistan. Intl J Disaster Risk Reduct 44: 101427. DOI: 10.1016/j.ijdrr.2019.101427.

Khandekar N, Gorti G, Bhadwal S, Rijhwani V. 2019. Perceptions of climate shocks and gender vulnerabilities in the Upper Ganga Basin. Environ Dev 31: 97-109. DOI: 10.1016/j.envdev.2019.02.001.

Kiptot E. 2015. Gender roles, responsibilities, and spaces: implications for agroforestry research and development in Africa. Intl For Rev 17 (4) 11-21. DOI: $10.1505 / 146554815816086426$.

Kiptot E, Franzel S. 2011. Gender and agroforestry in Africa: are women participating. ICRAF Occasional Paper, Kenya. DOI $10.5716 / \mathrm{OP} 16988$

Maharani YN, Lee S, Ki SJ. 2016. Social vulnerability at a local level around the Mt. Merapi volcano. Intl J Disaster Risk Reduct 20: 63-77. DOI: $10.1016 / j . i j d r r .2016 .10 .012$

Mulyoutami E, Roshetko JM, Martini E, Awalina D, Janudianto. 2015 Gender roles and knowledge in plant species selection and domestication: A case study in South and Southeast Sulawesi. Intl For Rev 17: 99-111. DOI: 10.1505/146554815816086453.

Mustaqim A. 2021. Kubah Lava Gunung Mt. Merapi Menurun Usai Guguran Awan Panas Tinggi (Mount Mt. Merapi's Lava Domes Decreased After High Heat Clouds Falling). Medcom.id. https://www.medcom.id/nasional/daerah/yNL4gBvN-kubah-lavagunung-Mt. Merapi-menurun-usai-guguran-awan-panas-tinggi

Napsiah N, Gunawan B, Abdoellah OS, Sulaeman M. 2017. Economic Rationality of Residents Living in the Area Prone to Mt. Merapi Volcanic Disaster. Komunitas Intl J Indon Soc Cult 9 (2): 203-215. DOI: $10.15294 /$ komunitas.v9i2.10002.
Nephawe N, Mwale M, Zuwarimwe J, Tjale MM. 2021. The impact of water-related challenges on rural communities food security initiatives. Agraris J Agribus Rural Dev Res 7 (1): 11-23.

Nofrita S, Krol BGCMB. 2014. The livelihood analysis in Mt. Merapi Prone Area After 2010 eruption. Indon J Geogr 46 (2): 195. DOI: 10.22146/ijg. 5790 .

Rahman MB, Nurhasanah IS, Nugroho SP. 2016. Community Resilience: Learning from Mt Mt. Merapi Eruption 2010. Procedia Soc Behav Sci 227: 387-394. DOI: 10.1016/j.sbspro.2016.06.090.

Rakib MA, Islam S, Nikolaos I, Bodrud-Doza M, Bhuiyan MAH. 2017.. Flood vulnerability, local perception and gender role judgment using multivariate analysis: A problem-based "participatory action to Future Skill Management" to cope with flood impacts. Weather Climate Extremes 18: 29-43. DOI: 10.1016/j.wace.2017.10.002.

Rampengan MM, Boedhiharto AK, Marguler C, Sayer J, Law L, Gaillard J, Ong T, Linh TTM. 2015. Agroforestry on an active volcanic small island in Indonesia: Prospering with adversity. Geogr Res 54 (1): 1934

Rao EJO, Qaim M. 2013. Supermarkets and agricultural labor demand in Kenya: A gendered perspective. Food Pol 38 (1): 165-176. DOI: 10.1016/j.foodpol.2012.11.008.

Ratdomopurbo A, Beauducel F, Subandriyo J, Agung Nandaka IGM, Newhall CG, Suharna, Sayudi DS, Suparwaka H, Sunarta. (2013). Overview of the 2006 eruption of Mt. Merapi. J Volcanol Geothermal Res 261: 87-97. DOI: 10.1016/j.jvolgeores.2013.03.019.

Rietveld AM, van der Burg M, Groot JCJ. 2020. Bridging youth and gender studies to analyse rural young women and men's livelihood pathways in Central Uganda. J Rural Stud 75: 152-163. DOI: 10.1016/j.jrurstud.2020.01.020

Rozaki Z, Rahmawati N, Wijaya O, Mubarok AF, Senge M, Kamarudin MF. 2021. A case study of agroforestry practices and challenges in Mt. Merapi risk and hazard-prone area of Indonesia. Biodiversitas 22 (6): 2511-2518. DOI: $10.13057 / \mathrm{biodiv} / \mathrm{d} 220661$.

Suryanto P, Hamzah MZ, Mohamed A, Alias MA. 2011. Silviculture agroforestry regime: compatible management in Southern Gunung Mt. Merapi National Park, Java, Indonesia. Intl J Biol 3 (2): 115-126.

Thompson-Hall M. 2016. Land Restoration, Agriculture, and Climate Change: Enriching Gender Programming Through Strengthening Intersectional Perspectives. In Land Restoration: Reclaiming Landscapes for a Sustainable Future. Elsevier, Nederland. DOI: 10.1016/B978-0-12-801231-4.00028-8.

Utami SNH, Purwanto BH, Marwasta D. 2018. Land Management for Agriculture After The 2010 Mt. Merapi Eruption. Planta Tropika J Agro Sci 6 (1): 32-38. DOI: 10.18196/pt.2018.078.32-38.

Villamor GB, Akiefnawati R, Van Noordwijk M, Desrianti F, Pradhan U. 2015. Land use change and shifts in gender roles in central Sumatra, Indonesia. Intl For Rev 17 (4): 61-75. DOI: $10.1505 / 146554815816086444$

Wikanto A. 2021. Gunung Mt. Merapi meletus lagi Rabu (27/1/2021) siang, warga turun mengungsi (Mount Mt. Merapi erupted again Wednesday (1/27/2021) afternoon, residents fled). Kontan.co.id. https://nasional.kontan.co.id/news/gunung-Mt. Merapi-meletus-lagirabu-2712021-siang-warga-turun- 